\title{
Biofilms on the surface of gravels and aquatic plants in rivers and lakes with reusing reclaimed water
}

\author{
Wang Tianzhi $\cdot$ Li Yunkai $\cdot$ Liang Mingchao $\cdot$ \\ Yang Peiling $\cdot$ Bai Zhihui
}

Received: 11 March 2013/Accepted: 6 December 2013/Published online: 22 December 2013

(C) Springer-Verlag Berlin Heidelberg 2013

\begin{abstract}
Reuse of reclaimed water for the eco-environmental water has become an effective measure to resolve the urban water crisis. However, it still contains large amounts of contaminants which may significantly affect the aquatic ecosystems. Biofilm attached on the surface of multiple matrixes in rivers and lakes is one of the indicators for describing the health of aquatic ecosystem. In this article, we chose eight rivers and lakes as the sampling locations, including three kinds of reclaimed water with different treatment processes and natural water. The morphology, structure and component characteristics of biofilms attached on the surface of aquatic plants and gravels in eight water bodies were evaluated. The results showed that the biofilm on the matrix surface were typical porous media with basic skeleton composed of inorganic particles, microorganisms and algae. The pores were filled with the viscous extracellular polymeric substances (EPS) secreted by microorganisms. The biofilms contained calcite, quartz, illite, alkali feldspar, dolomite, clinochlore, goethite and inorganic salt, and approximately $50 \%$ of these compositions are calcite and quartz. The concentration of EPS was $20.78-500.44 \mu \mathrm{g} / \mathrm{mL}$, and that of the gravel biofilms was less than that in aquatic plants by 18.1$75.3 \%$. In these three reclaimed waters, 4-7 kinds of PLFA (phospholipid fatty acid) were detected in aquatic plants biofilms, more than one or two kinds than in gravel
\end{abstract}

W. Tianzhi · L. Yunkai $(\bowtie) \cdot$ L. Mingchao $~ \cdot$ Y. Peiling Center for Agricultural Water Research in China, China Agricultural University, Beijing 100083, China

e-mail: liyunkai@126.com

B. Zhihui

State Key Laboratory of Urban and Regional Ecology, Research Center for Eco-Environmental Sciences, Chinese Academy of Sciences, Beijing 100085, China biofilms. And the dominant PLFA were i15:0 and 18:0, the total contents of which were, respectively, 74.4, 62.9 and $85.9 \%$ in the three kinds of reclaimed water. All biofilm samples contain major microorganisms such as Pseudomonas, Acinetobacter and Comamonas. This study is aimed to provide some support for assessing the health of riverlake ecosystem with biofilm indicator.

Keywords Reclaimed water - Rivers and lakes · Biofilm · Gravels · Aquatic plants

\section{Introduction}

Reclaimed water is usually reused for ecological maintenance of rivers and lakes in the world (Juanico and Friedler 1999; Huang and Wu 2008). Although the reclamation of water meets the discharge standard, it still contains a large amount of metal salts, organic pollutants, solid suspension particles, and microorganisms, which produce a serious impact on the aquatic ecosystems in the areas of reuse (Gan and Bai 2010). The most direct method for monitoring and evaluating the health status of the aquatic ecosystem is to monitor its biological status. The changes in biological communities in water can directly reflect on various chemical, physical, and biological factors and it also can reflect the health level of the aquatic ecosystem. Microorganisms in natural water contain bacteria, fungi, protozoa, metazoan and other species with characteristics of substantial amounts, various types, and fast propagation. It has become the important part of the aquatic ecosystem.

In fact, the majority of microbial organizations in water are not free. More than $90 \%$ of them are in the state of biofilm attached on the bottom surface of solid-substrate (Costerton et al. 1999). Biofilms are composed of microbial 
population (bacteria, protozoa, and fungi), inorganic minerals, and organic polymer matrix (EPS and humus). Biofilms have high surface reactivity and large adsorption area on pollutants (Reichert and Wanner 1997). The process of coalescence, adsorption and degradation of pollutants in biofilms reflect the combination of physical, chemical and biological purification, which plays an important role in the process of water self-purification (Sergi et al. 2002). The structure and compositions of the biofilm reflect the community, structure and function of water microorganism in the long-term evolution. It could become the most effective strategy to monitor and evaluate the health status of aquatic ecosystem. However, a large number of investigations regarding biofilms are focused on sewage treatment (Picioreanu et al. 2001), drainage (Percival and Letal 1998) and other engineering fields. Due to natural biofilms living in the complex environment, the researches about the attached biofilms on the surface of pebbles and other sediments are limited to rivers (Qin 2008), lakes (Dong et al. 2005), wetlands and oceans (Baty and Metal 1996). The sampling methods of biofilm at present are usually focused on artificial inert matrix, and few reports with in on-situ sampling. Major water quality index of reclaimed water is between those of wastewater and natural water, which lead to special characteristics of attached biofilms in reclaimed water, but there are few reports about it so far (Liang et al. 2013). Now, some new methods, such as modern electron microscope, precise analysis and molecular biology have been developed quickly, and they make it possible to test the characteristics of biofilms.

Based on this study, the biofilms attached on aquatic plants and gravels in the natural and reclaimed water with different sewage treatment processes have been studied by the on-situ sampling. The morphology, structure and component characteristics of biofilms have been explored by environmental scanning electron microscope (ESEM), $\mathrm{X}$-ray diffraction, PLFA biomarkers, polymerase chain reaction denaturing gradient gel electrophoresis (PCRDGGE), and so on. It will provide a theoretical basis to assess the purification capacity and health status of aquatic systems.

\section{Materials and methods}

\section{Sampling locations}

The reclaimed water with three kinds of sewage treatment processes and natural reservoir bodies were chosen as the experimental subjects, including combinatorial process of deposition and sand filtration, traditionally activated sludge process and UF membrane filtration plus anaerobic-anoxic- oxic process were chosen. Biofilms attached on the surface of gravels and aquatic plants were sampled and tested. The sampling locations and its information are shown in Fig. 1 and Table 1 . The sampling points were all in the center of lakes or rivers; $500 \mathrm{~mL}$ water of each sample was collected and kept at constant temperature of $-4{ }^{\circ} \mathrm{C}$.

Meanwhile, the water quality was tested based on water and exhausted water monitoring analysis method. The results in Table 2 revealed that the contents of nitrate, total nitrogen, total phosphorus, biochemical oxygen demand $\left(\mathrm{BOD}_{5}\right)$, chemical oxygen demand $\left(\mathrm{COD}_{\mathrm{cr}}\right)$, water-soluble phosphorus and bicarbonate in reclaimed water are approximately two times as high as that in surface water. Ammonia nitrogen is approximately five times higher than that in surface water; in contrast, the sulfate is only $1 / 5$ of that in surface water. Therefore, the quality characteristics of municipal reclaimed water are among sewage water and natural water.

\section{Collection and preparation of biofilm samples}

Two kinds of biofilms samples were collected at each sampling location. One part of samples was used to examine surface morphology, and the samples were put in a ziplock and then transferred to the refrigerator in the laboratory as soon as possible. Ultrasonic vibration was used to detach the biofilms from the surface of the matrix. The suspension was divided into two parts. One part was used for PLFA and PCR-DGGE. Another part was used to analyze EPS compositions and inorganic chemical components.

\section{SEM scanning}

Biofilm samples were cut into small slices with the dimension of $0.6 \times 0.6 \mathrm{~cm}$, and then treated as following procedures: (1) fixation: the small slices of biofilms were fixed in $2.5 \%$ glutaraldehyde solution, followed by the rinse with $0.1 \mathrm{M}$ sodium phosphate buffer for three times (15 min for each rinse). After washing, the small biofilm slices were fixed in $1 \%$ osmium tetroxide $\left(\mathrm{OsO}_{4}\right)$ for $3 \mathrm{~h}$, and then rinsed with $0.1 \mathrm{M}$ sodium phosphate buffer for three times (15 min for each). (2) Dehydration: the biofilm samples were dehydrated in ethanol at the concentrations of $30,50,70,85$ and $95 \%$ for 5 min at each concentration condition, and then dehydrated in $100 \%$ ethanol for three times (15 min for each). (3) Drying: carbon dioxide critical point drying was conducted through BAL-TEC CPD030. (4) Gold spray: gold spray-ion sputtering instrument BALTEC SCD005 was used to glide. (5) Photograph: scanning electron microscope FEIQUANTA200 was used for imaging. All images were acquired with magnification of $5,000 \times$. 
Fig. 1 Sampling locations. Labe (1) is Yongdinghe Mencheng Lake; Labe (2) is Yongdinghe Lianshi Lake; Labe (3) is Bahe River; Labe (4) is Honglingjin Park Lake; Labe (5) is South Hucheng River; Labe (6) is Taoranting Park Lake; Labe (7) is Qinghe River; Labe (8) is Aoyun Lake

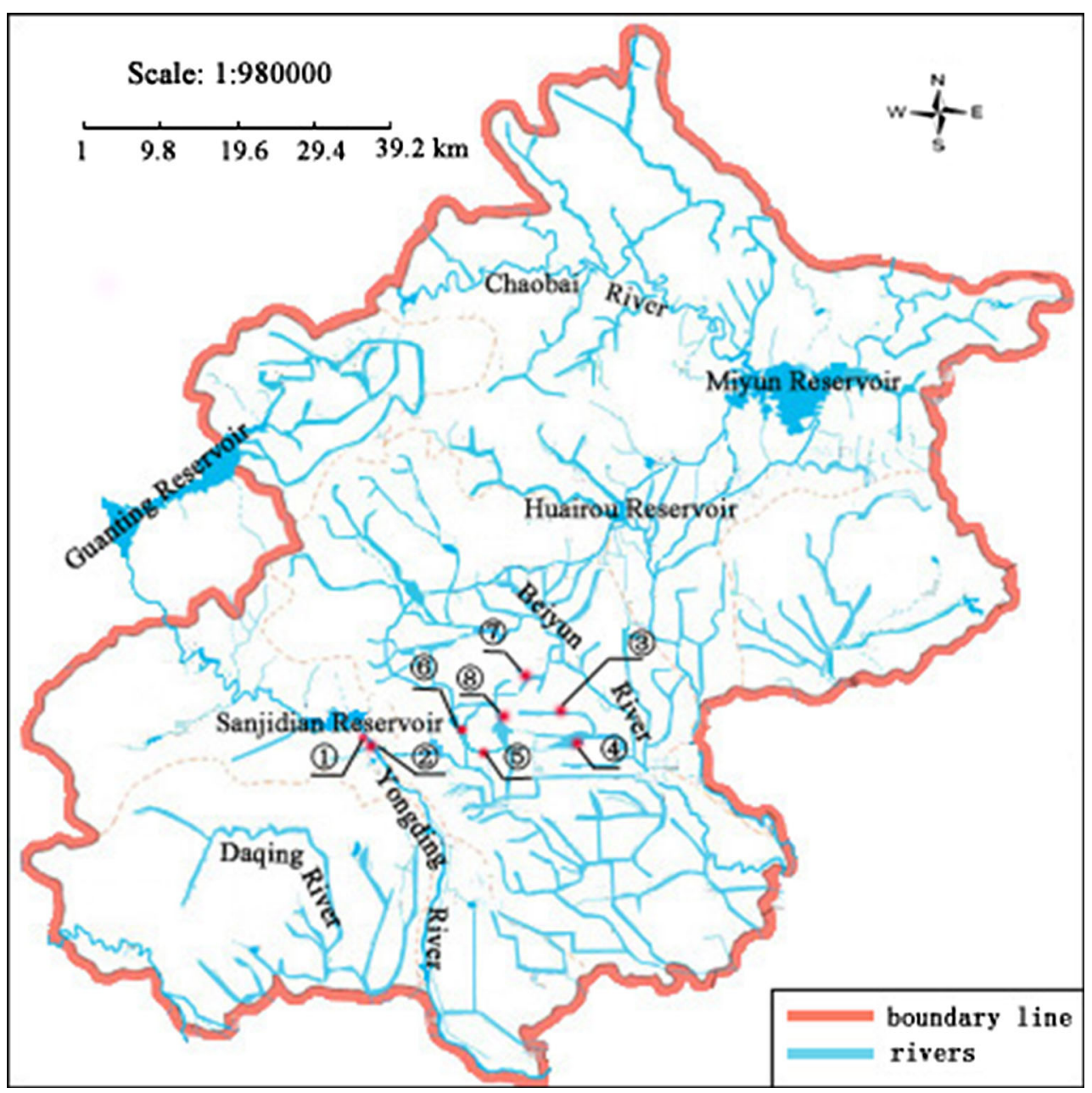

X-ray diffractometer

Solid biofilms were ground uniformly and scanned by D8Advance X-ray diffractometer. The polycrystal diffraction patterns were achieved. The basic scanning conditions were voltage of $40 \mathrm{kV}$, current of $40 \mathrm{~mA}, \mathrm{Cu}$ as the target, and wavelength of $1.5406 \AA$. In order to determine the phase, the resultant maps were analyzed through Topas software.

\section{EPS test}

EPS is composed of proteins, polysaccharides, nucleic acids, uronic acids, lipids, humic acids and amino acids. Among them, extracellular proteins and extracellular polysaccharides are major components with the content of 70-80 \% (Hong and Herbert 2002; Frølund et al. 1996). Phenol sulfuric acid method and Lowry method were used to test extracellular polysaccharides and extracellular proteins (Lowry et al. 1951; Nocker et al. 2007), respectively.
Diversity test of PLFA biomarkers

PLFA test was referred to the analytical methods described by Pennanen et al. (1999). The test processes included PLFA extraction from the biofilms, purification, methylation, gas chromatography-mass spectroscopic (GC-MS) analysis, biomass assessment, bacterial PLFA determination in biofilms and data analysis.

\section{PCR-DGGE map test}

The test processes were as follows (Xing et al. 2005): (1) microbial genomic DNA was extracted by chemical cleavage method after slight modifications, and the genomic DNA directly extracted from bacterial samples was purified according to previous descriptions (Sandhu et al. 2007). (2) The genomic DNA was purified using glass bead DNA gel extraction kit according to the manufacture's instructions (product number: SK111, Shanghai Sangon). (3) Genomic DNA was amplified by PCR. (4) DGGE maps of PCR amplified products were achieved by DGGE. (5) 
Table 1 Sampling locations and reference

\begin{tabular}{|c|c|c|c|c|c|c|c|}
\hline Water body type & $\begin{array}{l}\text { Treatment } \\
\text { process }\end{array}$ & Recharge water source & $\begin{array}{l}\text { Names of } \\
\text { river and lake }\end{array}$ & Area $\left(\mathrm{m}^{2}\right)$ & Matrix type & Reference & GPS \\
\hline \multirow[t]{4}{*}{ Natural water } & \multirow[t]{4}{*}{-} & \multirow[t]{4}{*}{ Sanjiadian reservoir } & \multirow{2}{*}{$\begin{array}{l}\text { Yongdinghe } \\
\text { Mencheng Lake } \\
\text { (SML) }\end{array}$} & \multirow[t]{2}{*}{$0.67 \times 10^{6}$} & Gravels & SMLS & $\mathrm{N} 39^{\circ} 57^{\prime}$ \\
\hline & & & & & $\begin{array}{r}\text { Aquatic } \\
\text { plants }\end{array}$ & SMLP & E116 $06^{\prime}$ \\
\hline & & & \multirow{2}{*}{$\begin{array}{l}\text { Yongdinghe Lianshi } \\
\text { Lake (SLL) }\end{array}$} & \multirow[t]{2}{*}{$10^{6}$} & Gravels & SLLS & $\mathrm{N} 39^{\circ} 56^{\prime}$ \\
\hline & & & & & $\begin{array}{r}\text { Aquatic } \\
\text { plants }\end{array}$ & SLLP & $\mathrm{E} 116^{\circ} 06^{\prime}$ \\
\hline \multirow{12}{*}{$\begin{array}{l}\text { Reclaimed } \\
\text { water }\end{array}$} & \multirow{4}{*}{$\begin{array}{l}\text { Deposit and sand } \\
\text { filtration process }\end{array}$} & Jiuxianqiao & \multirow[t]{2}{*}{ Bahe (RJR) } & \multirow[t]{2}{*}{$158.4 \times 10^{6}$} & Gravels & RJRS & $\mathrm{N} 39^{\circ} 58^{\prime}$ \\
\hline & & $\begin{array}{l}\text { Reclaimed water } \\
\text { works }\end{array}$ & & & $\begin{array}{r}\text { Aquatic } \\
\text { plants }\end{array}$ & RJRP & $\mathrm{E} 116^{\circ} 33^{\prime}$ \\
\hline & & & \multirow{2}{*}{$\begin{array}{l}\text { Honglingjin Park } \\
\text { Lake (RJL) }\end{array}$} & \multirow[t]{2}{*}{$0.16 \times 10^{6}$} & Gravels & RJLS & $\mathrm{N} 39^{\circ} 55^{\prime}$ \\
\hline & & & & & $\begin{array}{r}\text { Aquatic } \\
\text { plants }\end{array}$ & RJLP & $\mathrm{E} 116^{\circ} 29^{\prime}$ \\
\hline & \multirow{4}{*}{$\begin{array}{l}\text { Conventional ly } \\
\text { activated sludge } \\
\text { process }\end{array}$} & Gaobeidian & \multirow{2}{*}{$\begin{array}{l}\text { South Hucheng } \\
\text { River (RGR) }\end{array}$} & \multirow[t]{2}{*}{$0.77 \times 10^{6}$} & Gravels & RGRS & $\mathrm{N} 39^{\circ} 52^{\prime}$ \\
\hline & & $\begin{array}{l}\text { Reclaimed water } \\
\text { works }\end{array}$ & & & $\begin{array}{r}\text { Aquatic } \\
\text { plants }\end{array}$ & RGRP & $\mathrm{E} 116^{\circ} 24^{\prime}$ \\
\hline & & & \multirow{2}{*}{$\begin{array}{l}\text { Taoranting Park } \\
\text { Lake (RGL) }\end{array}$} & \multirow[t]{2}{*}{$0.17 \times 10^{6}$} & Gravels & RGLS & $\mathrm{N} 39^{\circ} 53^{\prime}$ \\
\hline & & & & & $\begin{array}{r}\text { Aquatic } \\
\text { plants }\end{array}$ & RGLP & $\mathrm{E} 116^{\circ} 22^{\prime}$ \\
\hline & \multirow{4}{*}{$\begin{array}{l}\text { Ultrafiltration ozone } \\
\text { process }\left(\mathrm{A}^{2} / \mathrm{O}\right)\end{array}$} & Qinghe & \multirow[t]{2}{*}{ Qinghe (RQR) } & \multirow[t]{2}{*}{$50.2 \times 10^{6}$} & Gravels & RQRS & $\mathrm{N} 40^{\circ} 01^{\prime}$ \\
\hline & & $\begin{array}{l}\text { Reclaimed water } \\
\text { works }\end{array}$ & & & $\begin{array}{r}\text { Aquatic } \\
\text { plants }\end{array}$ & RQRP & $\mathrm{E} 116^{\circ} 21^{\prime}$ \\
\hline & & & \multirow[t]{2}{*}{ Aoyun Lake (RQL) } & \multirow[t]{2}{*}{$1.2 \times 10^{6}$} & Gravels & RQLS & $\mathrm{N} 40^{\circ} 00^{\prime}$ \\
\hline & & & & & $\begin{array}{l}\text { Aquatic } \\
\text { plants }\end{array}$ & RQLP & $\mathrm{E} 116^{\circ} 24^{\prime}$ \\
\hline
\end{tabular}

$S M$ Yongdinghe Mencheng Lake, $S L$ Yongdinghe Lianshi Lake, $R J$ combinatorial process of deposit and sand filtration in Jiuxianqiao reclaimed water works, $R G$ traditionally activated sludge process in Gaobeidian reclaimed water works, $R Q$ ultrafiltration ozone process (A $\left.{ }^{2} / \mathrm{O}\right)$ in $\mathrm{Qinghe}$ reclaimed water works, $R$ rivers, $L$ lakes, $S$ gravels, and $P$ aquatic plants

Table 2 Test results of water quality $(\mathrm{mg} / \mathrm{L})$

\begin{tabular}{|c|c|c|c|c|c|c|c|c|c|c|c|c|c|}
\hline Reference & $\mathrm{NH}_{4}-\mathrm{N}$ & $\mathrm{NO}_{3}^{-}$ & $\mathrm{TN}$ & $\mathrm{TP}$ & $\mathrm{BOD}_{5}$ & $\mathrm{COD}_{\mathrm{Cr}}$ & SP & $\mathrm{Ca}^{2}$ & $\mathrm{Mg}^{2}$ & $\mathrm{PO}_{4}{ }^{3-}$ & $\mathrm{SO}_{4}{ }^{2-}$ & $\mathrm{HCO}_{3}^{-}$ & $\mathrm{pH}$ \\
\hline SML & 0.40 & 5.47 & 7.44 & 0.04 & 4.2 & 4 & 0.02 & 105 & 33.9 & 0.06 & 365 & 170 & 7.44 \\
\hline SLL & 0.39 & 2.71 & 4.58 & 0.11 & 6.6 & 29.7 & 0.05 & 43.7 & 34 & 0.02 & 247 & 125 & 7.92 \\
\hline RJH & 3.24 & 11.6 & 16.2 & 0.38 & 11.8 & 47.7 & 0.32 & 75 & 31.7 & 0.96 & 100 & 344 & 7.54 \\
\hline RJL & 0.81 & 0.88 & 1.80 & 0.22 & 8.8 & 38.2 & 0.08 & 29.1 & 20.8 & 0.24 & 78.7 & 163 & 7.86 \\
\hline RGR & 0.46 & 7.17 & 9.38 & 0.11 & 4 & 19.7 & 0.1 & 56.9 & 20.5 & 0.22 & 97.6 & 197 & 7.7 \\
\hline RGL & 0.24 & 4.75 & 6.34 & 0.03 & 4.2 & 20.9 & 0.01 & 40.9 & 22.7 & 0.02 & 122 & 125 & 8.22 \\
\hline RQR & 15.8 & 9.07 & 28.6 & 0.82 & 8.2 & 36.2 & 0.5 & 63.6 & 21.1 & 16.1 & 93.2 & 298 & 7.21 \\
\hline RQL & 0.33 & 3.78 & 5.46 & 0.17 & 3.9 & 19.3 & 0.14 & 36.8 & 22 & 0.34 & 92.9 & 110 & 9.34 \\
\hline
\end{tabular}

Recovery and sequencing of the bands; (6) Phylogenetic analysis: the sequences were input in the National Center for Biotechnology Information Webs (http://www.ncbi.nih. gov) when compared with the sequences in GenBank and the program, BLAST. The highest homology of the sequence and the high homology of the known species sequences as the references were downloaded. Phylogenetic analysis was completed by software Clustal X1.81 and Mega 3 through N-J method, and a phylogenetic tree was conducted (Kumar et al. 2004). Totally 1,000 duplicate detections were used to validate the confidence of the phylogenetic tree by bootstrap (Felsenstein 1985).

\section{Results and discussion}

Biofilms surface formation characteristics

The formation of biofilms is highly correlated with hydrologic conditions, basement types, nutrition level, light 
and other factors (Qin 2008). The proper basement types for the reproduction of bacteria in water include inert surface (gavels) and active surface (underwater part of aquatic plants). So the structural characteristics of biofilms were comprehensive performance under many factors. The structural characteristics of biofilms attached on the surface of gravels and aquatic plants are shown in Figs. 2 and 3, which exhibited that the biofilms attached on the surfaces of 16 kinds of matrix had obvious porosity as a kind of typical porous matrix, whose surface adsorbed a large number of particles including inorganic particles and organisms (rod-shaped bacteria, spherical bacteria, filamentous bacteria and ring bacteria) (Figs. 2, 3). The pores were filled with lots of EPS that was a viscous substance secreted by bacteria ( $\mathrm{Li}$ et al. 2002). Because of the stickiness of EPS, the microbial communities and attachment were connected together to form stable network and heterogeneous porous structure. In addition, as shown in Fig. 3a-h, totally $2-5$ kinds of fungi could be observed in the biofilms of aquatic plants and five kinds of fungi were from Aoyun Lake. Figure $2 \mathrm{a}-\mathrm{h}$ reveals 1-2 kinds of fungi on the surface of gravels. When comparing (a), (c), (e), (g) with (b), (d), (f), (h) in Fig. 3, the content of algae in the biofilms of the lake is more than that of the river.

\section{Biofilms inorganic components}

Figure 4 shows the XRD maps (Aoyun Lake for example) of biofilms with X-ray, and Table 3 shows the results of quantitative analysis of inorganic components. It could be deduced that biofilms contain calcite, quartz, illite, alkali feldspar, dolomite, clinochlore, goethite, and inorganic salt. Calcite, quartz, illite, alkali feldspar, and dolomite were the major inorganic compositions in the biofilms, and the content of each substance was more than $10 \%$. Calcite and quartz revealed the highest contents and reached $50 \%$. Calcite was the most major component in the aquatic plant biofilms in the reclaimed and natural water with the contents of 31.30 and $43.21 \%$, respectively; while quartz was the most major component in the gravel biofilms with the contents of 23.85 and $35.54 \%$, respectively. Dolomite and clinochlore were the minor components of the biofilms, and the content of each substance was 5-10\%. Similarly, a small amount of goethite and inorganic salt was detected within $5 \%$.

Compared with the biofilms from the reclaimed water, natural water body and sewage, the major chemical elements in reclaimed water biofilms were similar to that in natural water biofilms and different from that in sewage, but the difference of biofilms between reclaimed water and natural water was minor elements and trace elements. The contents of chemical elements in biofilms from natural water body were determined by using inductively coupled plasma emission spectrometer (ICO-AES) (Wang et al. 2002), and the result showed that $\mathrm{Ca}, \mathrm{Mg}, \mathrm{K}, \mathrm{Na}, \mathrm{Al}, \mathrm{Fe}$, and $\mathrm{S}$ were the major elements in biofilms; and $\mathrm{Mn}, \mathrm{Sr}, \mathrm{Ti}$, $\mathrm{P}$, and $\mathrm{La}$ were the minor elements; and $\mathrm{Co}, \mathrm{Cu}, \mathrm{Pb}, \mathrm{Li}, \mathrm{B}$, $\mathrm{Ni}, \mathrm{Ce}, \mathrm{V}, \mathrm{Be}$, and $\mathrm{Cr}$ were the trace elements. Meanwhile, the content of iron oxide and aluminum oxide was higher than that of manganese oxide in biofilms in natural water (Dong et al. 2005, 2006). In addition, the contents of As, $\mathrm{Ni}$ and $\mathrm{Zn}$ in sewage biofilms were more than $30 \%$ (Hu et al. 2005). This is mainly due to the degradation or absorption of heavy metal pollutants during sewage treatments and draining the reclaimed water into rivers and lakes, correspondingly resulting in the lower contents of $\mathrm{As}, \mathrm{Ni}$ and $\mathrm{Zn}$ in reclaimed water than that in sewage (Hu et al. 2005). Furthermore, for the biofilms on the surface of gravels, there was no obvious rule for the content of calcite and quartz during the three treatment processes. However, for the biofilms on the surface of aquatic plants, the content of calcite in reclaimed water was lower than that in natural reservoir by $41.93,9.05$ and $32.84 \%$, respectively, while the content of quartz in reclaimed water was higher than that in natural reservoir by $33.77,27.38$ and $24.55 \%$, respectively.

\section{Biomarker diversity of PLFA in biofilms}

Different microorganisms contain different species and quantities of PLFA, especially some fatty acids in microbial cell membranes. Phospholipids can decompose rapidly after cell death and can represent the part activity of the cells. Therefore, PLFAs can be used as the biomarkers of microbial biomass and the indicators of the change in community structure (Pennanen et al. 1999). The results of PLFA biomarkers have shown in Fig. 5, which exhibited that the types and contents of the epiphytic microbial community in biofilms on the surface of different matrix from different water bodies were listed. The PLFA biomarkers in the biofilms contained i13:0, 14:0, i15:0, 15:0,

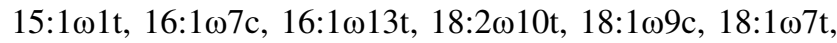

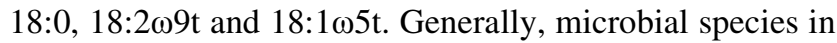
the biofilms had 2-7 species. The species of PLFA in the biofilm on the aquatic plant surface were obviously more than those on the gravel surface. Similarly, the species on the aquatic plant surface generally also had 4-7 species; in contrast, the species on the gravel surface generally had 2-6 species. Compared with the biofilms microbial species in the sewage, the biofilms microbial species in the reclaimed water were obviously less. Similarly, 12 genera (species) of bacteria, 3 genera of fungi, 14 genera (species) of protozoa, 2 genera of metazoan, 2 genera of oligochaetes and crustaceans and 6 large groups among 35 species of microorganisms have been detected when the characteristics of biofilm microbial community in 
Fig. 2 SEM images of biofilms on gravel surfaces. a SMLS, b SLLS, $\mathbf{c}$ RJRS, d RJLS, e RGRS, f RGLS, $\mathbf{g}$ RQRS, $\mathbf{h}$ RQLS. Labe (1) is the bacilli in the shapes of the character; Labe (2) is cocci; Labe (3) is algae; Labe (4) is the bacilli in the shapes of the word

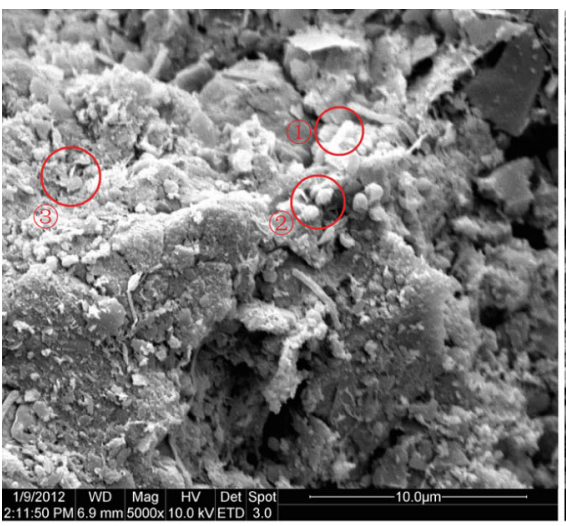

(a)

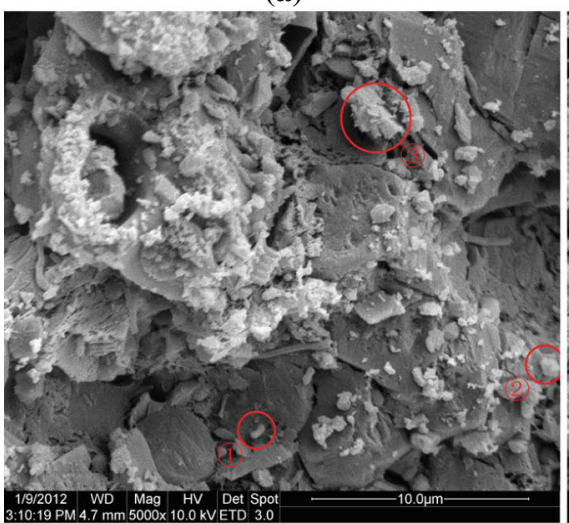

(c)

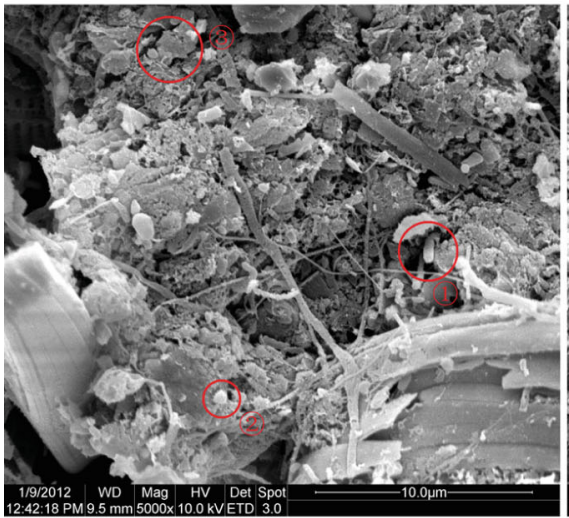

(e)

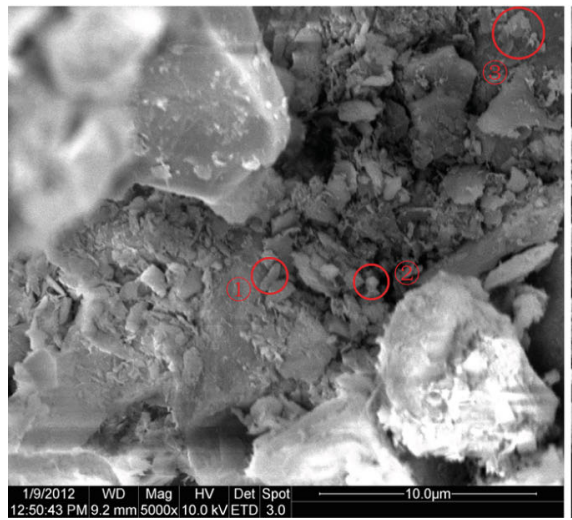

(g)

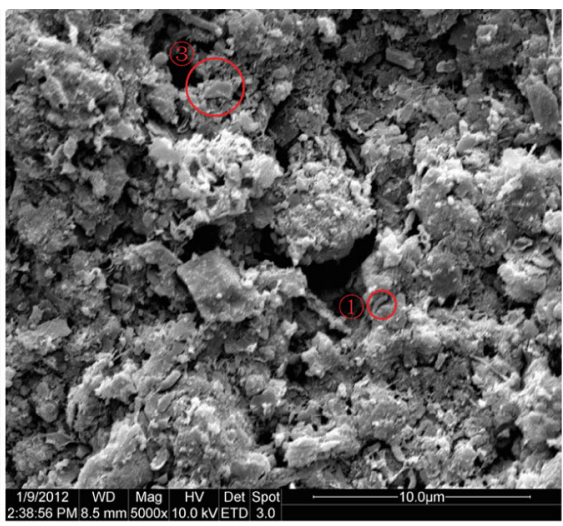

(b)

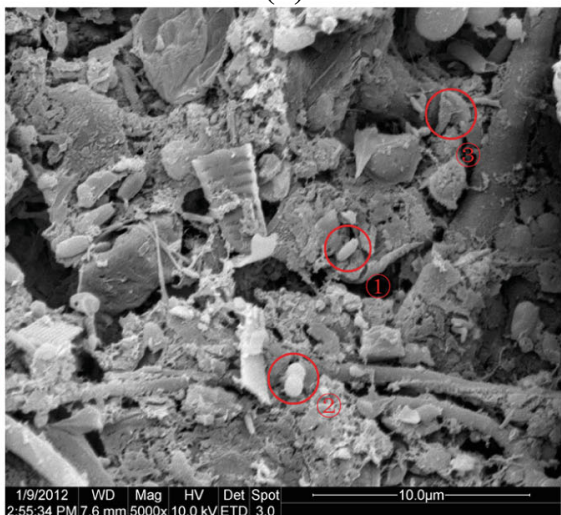

(d)

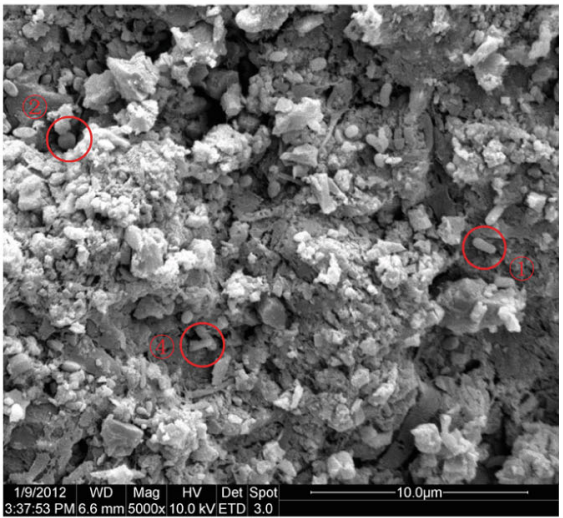

(f)

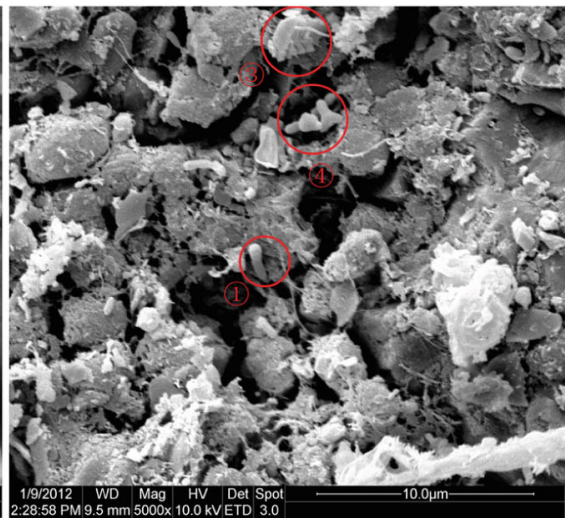

(h) 
Fig. 3 SEM images of biofilms on plant surfaces. a SMLP, b SLLP, $\mathbf{c}$ RJRP, d RJLP, e RGRP, f RGLP, $\mathbf{g}$ RQRP, $\mathbf{h}$ RQLP. Labe (1) is the bacilli in the shapes of the character; Labe (2) is cocci; Labe (3) is algae; Labe (4) is the bacilli in the shapes of the word; Labe (5) is mold fungi; Labe (6) is ring bacteria
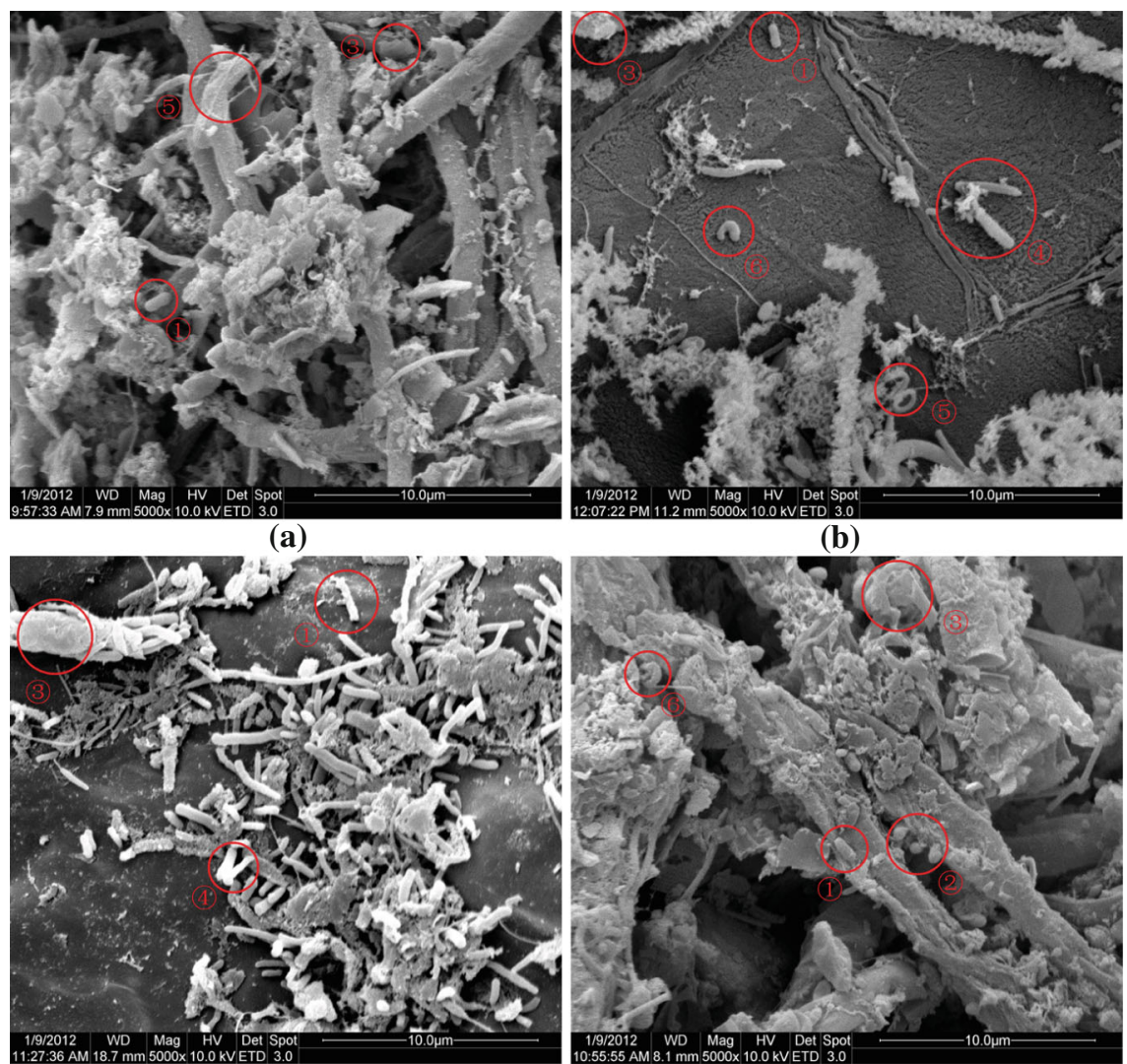

(c)

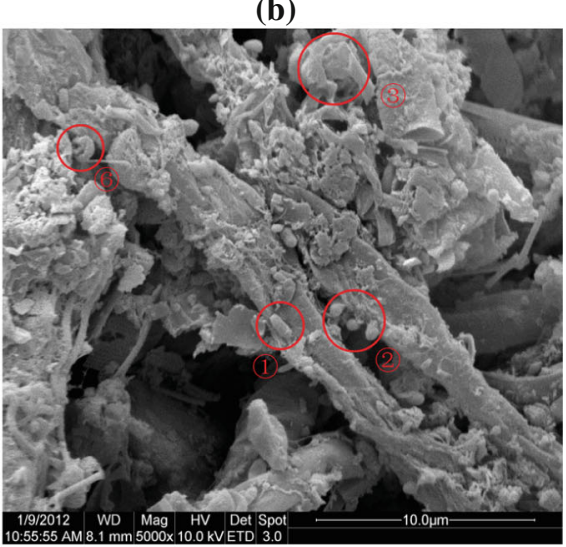

(d)

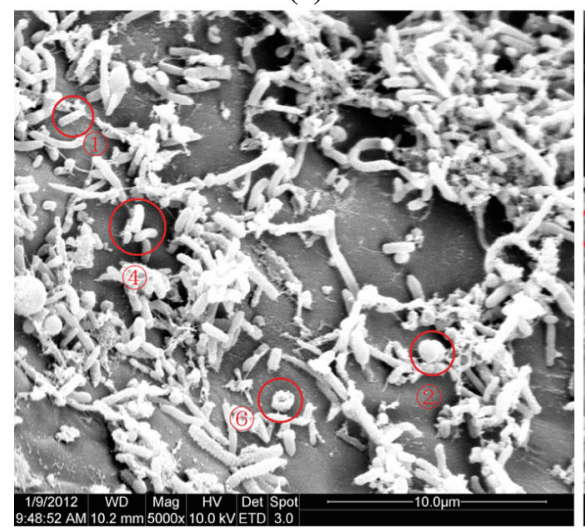

(e)
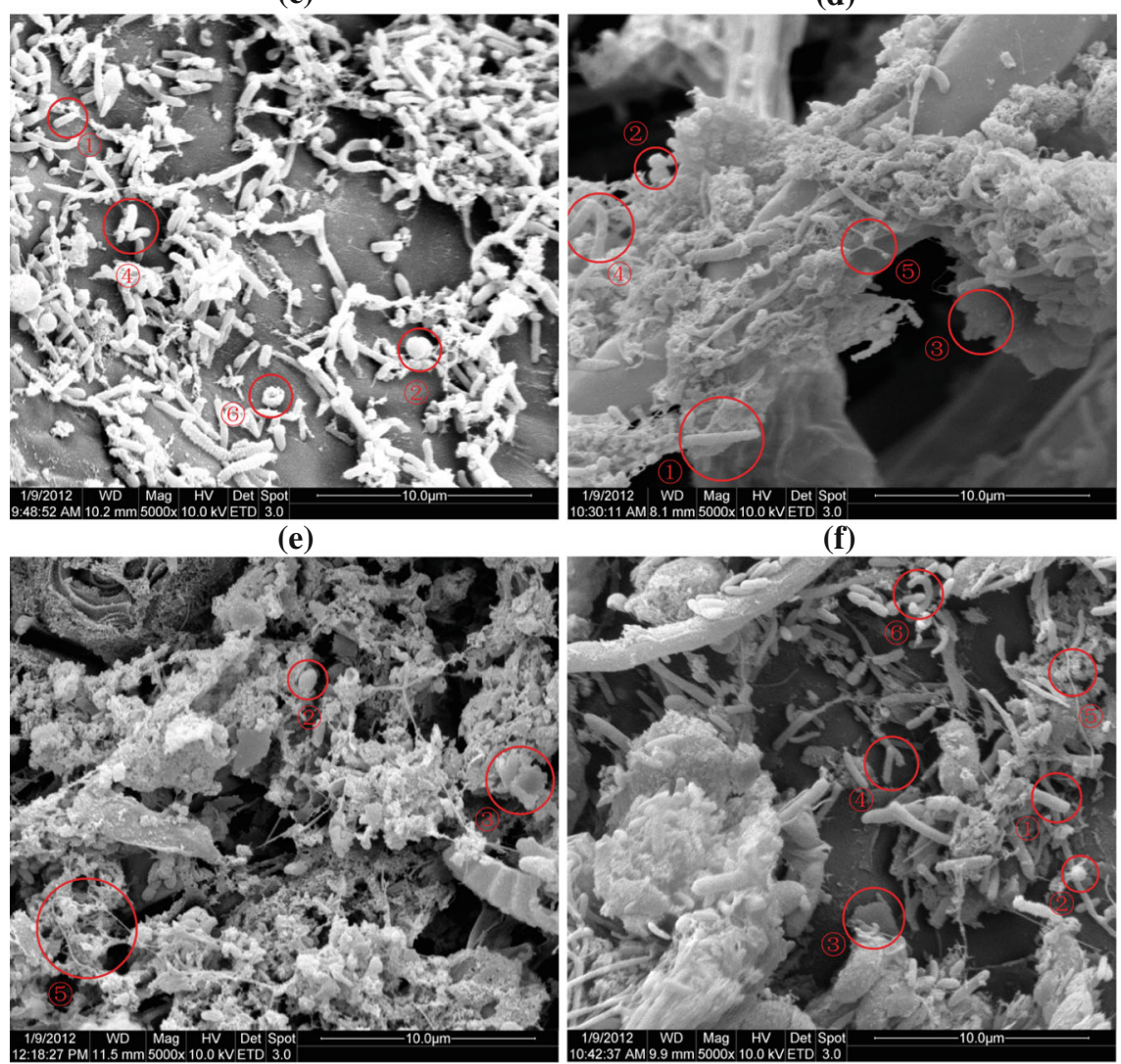

(g)

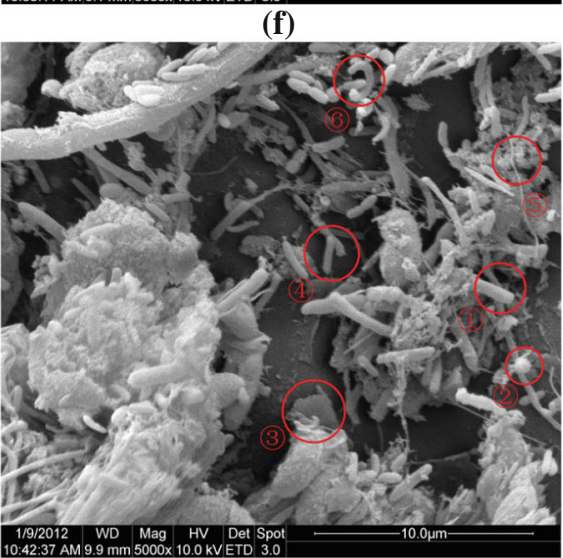

(h) 
Fig. 4 The XRD mapping of biofilm. a the gravel surface of RQL. b The plant surface of RQL

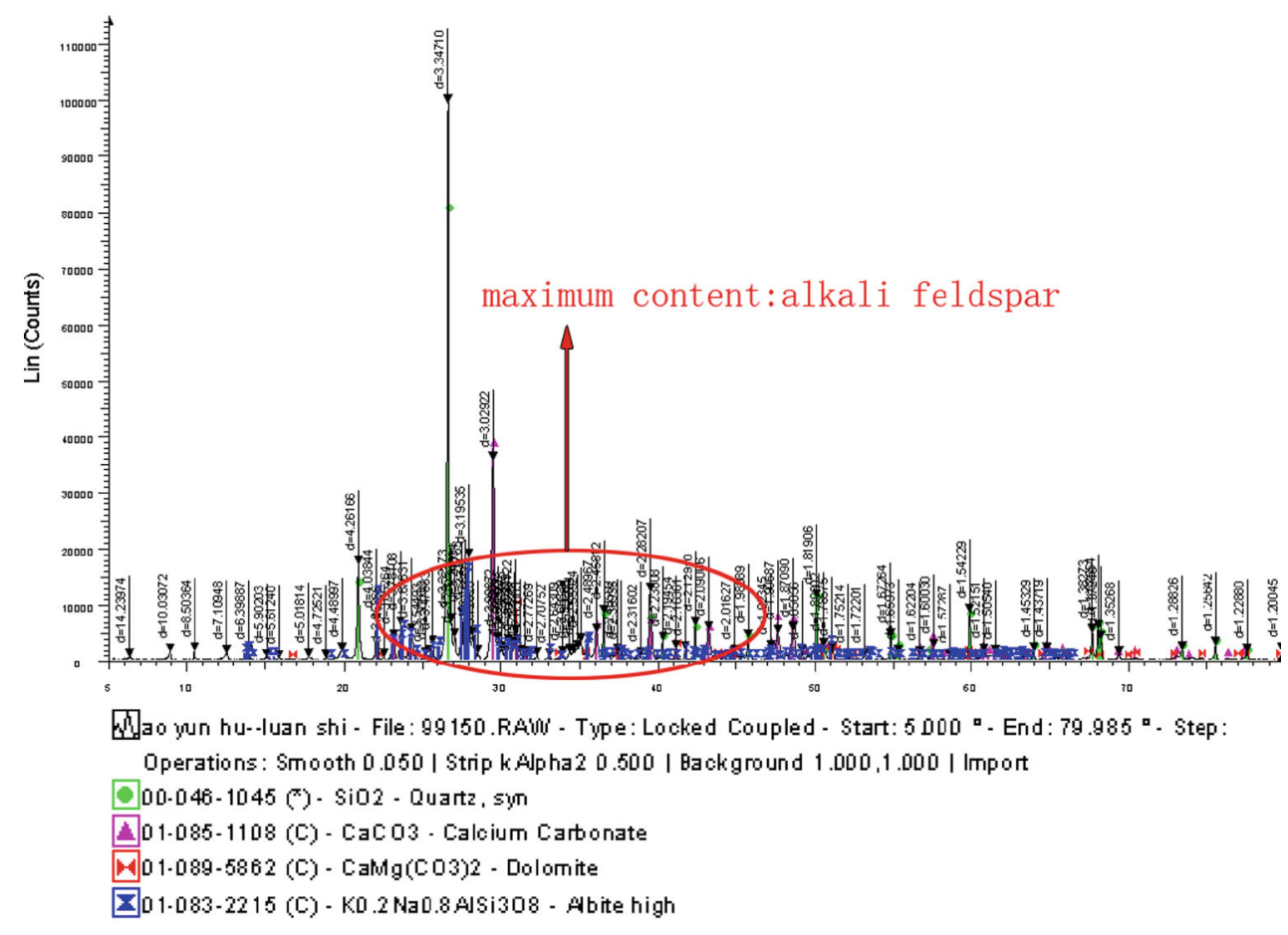

(a)

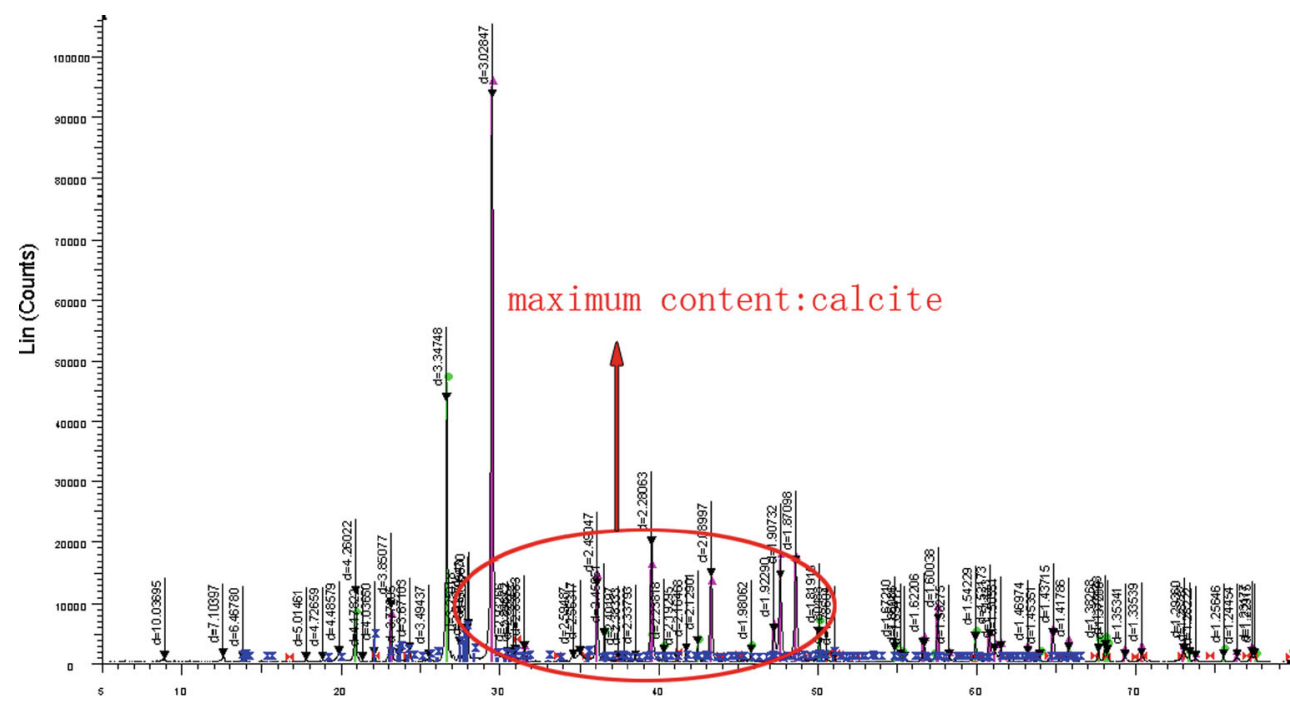

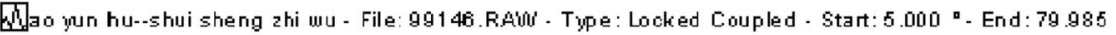
Operations: Smooth 0.050 । Strip kAjpha2 0.500 । Background 0.000.1.000 । Import 000-045.1045 (\%) Si02 - Hexagonal - Quartz, syn

a 1-085-1108 (C) - CaC03 - Rhombo.H.axes - Calcium Carbonate M01-089-5862 (C) - Calug(C 03)2 - Rhombo.H.axes - Dolomite 国01-083.2215 (C) - K0.2Na0.8Al\$308 - Triclinic - Absite high

(b)

sewage were explored (Qiu and Ma 2005; Yu et al. 1990). The dominant bacteria in the sewage biofilm were ammonia-oxidized bacteria and nitrite-oxidized bacteria (Fdz-Polanco et al. 1996). The main reason of the above is that there are much more nutrients and pollutants in the sewage than in the other two water bodies (Gan and Bai 2010). So the sewage can provide enough nutrients for microorganisms. Thus, fewer microorganisms in the reclaimed water biofilm were observed than in the sewage biofilm. 
Table 3 Phase compositions and contents of attached biofilms from different water bodies and different matrix

\begin{tabular}{|c|c|c|c|c|c|c|c|c|}
\hline Reference & Calcite & Quartz & Alkali feldspar & Illite & Clinochlore & Dolomite & Goethite & Inorganic salt \\
\hline SMLS & 20.82 & 27.97 & 23.67 & 14.57 & 7.31 & 5.25 & 0.41 & 0 \\
\hline SMLP & 44.65 & 12.82 & 14.29 & 10.58 & 10.97 & 1.61 & 3.29 & 1.79 \\
\hline SLLS & 19.88 & 35.1 & 24.14 & 10.16 & 8.68 & 1.38 & 0.11 & 0.55 \\
\hline SLLP & 41.76 & 22.54 & 13.93 & 10.32 & 10.05 & 0.9 & 0 & 0.5 \\
\hline RJRS & 19.72 & 15.32 & 30.17 & 10.91 & 8.55 & 12.86 & 1.56 & 0.93 \\
\hline RJRP & 22.93 & 28.44 & 18.78 & 16.92 & 7.98 & 4.96 & 0 & 0 \\
\hline RJLS & 32.18 & 23.43 & 16.97 & 15.77 & 9.3 & 1.44 & 0.25 & 0.65 \\
\hline RJLP & 27.25 & 18.86 & 12.49 & 18.16 & 19.83 & 3.42 & 0 & 0 \\
\hline RGRS & 25.46 & 18.57 & 14.63 & 7.25 & 6.47 & 26.45 & 0.64 & 0.53 \\
\hline RGRP & 68.6 & 9.24 & 10.74 & 7.97 & 1.51 & 1.77 & 0.17 & 0 \\
\hline RGLS & 28.48 & 19.29 & 20.38 & 11.88 & 7.07 & 12.23 & 0 & 0.67 \\
\hline RGLP & 10 & 35.8 & 26.35 & 15.08 & 8.62 & 3.48 & 0 & 0.67 \\
\hline RQRS & 5.21 & 38.33 & 29.97 & 11.15 & 11.24 & 2.25 & 1.14 & 0.72 \\
\hline RQRP & 3.02 & 26.56 & 29.15 & 15.75 & 13.64 & 6.68 & 3.99 & 1.21 \\
\hline RQLS & 20.91 & 28.14 & 30.52 & 10.17 & 6.53 & 2.92 & 0.14 & 0.68 \\
\hline RQLP & 56.02 & 17.52 & 12.59 & 6.72 & 5.33 & 1.05 & 0.2 & 0.57 \\
\hline
\end{tabular}

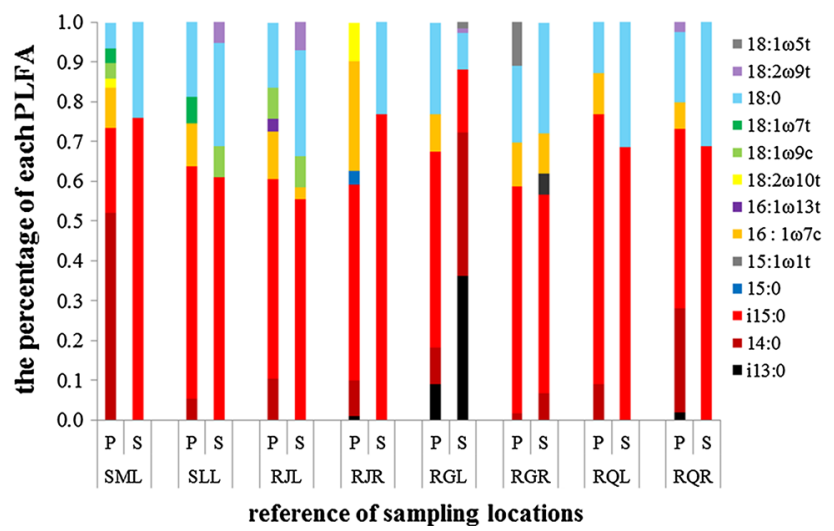

Fig. 5 The concentration of PLFAs from sixteen biofilms. $S$ gravels, $P$ aquatic plants

Besides, as shown in Fig. 5, i15:0 and 18:0 were the major PLFA in the biofilms from natural water and the reclaimed water with three kinds of wastewater treatment processes. The sum of both reached up to 74.4, 62.9, 85.9 and $72.8 \%$, respectively; while the biofilm from the reclaimed water with the combinatorial process of coagulation and sand filtration also contained the major PLFA $16: 1 \omega 7 \mathrm{c}$ with the content of $10.7 \%$ and the biofilm of the reclaimed water with the traditionally activated sludge process contained the major PLFA 14:0 and i13:0 with the contents of 22.0 and $11.3 \%$, respectively. On the surface of gravels, the contents of i15:0 and 18:0 in the biofilm in the reclaimed water with the traditionally activated sludge process were lower by 51.8 and $26.3 \%$ than those in the biofilm in the natural reservoir water. However, no significant difference between other two kinds of reclaimed waters and natural reservoir water for the aquatic plant surface was observed. The contents of the i15:0 in three kinds of reclaimed water biofilms were higher by 24.9, 33.4 and $42.0 \%$ than those in natural reservoir water. In contrast, the contents of 14:0 in three kinds of reclaimed water biofilms were lower by $66.3,81.3$ and $38.5 \%$, respectively. As for different kinds of wastewater treatment processes, a number of unique PLFA in the biofilm were detected. For example, 15:0 and 16:1 $113 \mathrm{t}$ were in the water biofilms with combinatorial process of coagulation and sand filtration. $15: 1 \omega 1 \mathrm{t}$ and $18: 1 \omega 5 \mathrm{t}$ were in water biofilms with the traditionally activated sludge process. However, 18:1 $107 \mathrm{t}$ was in the biofilm on the surface of aquatic plants.

Biofilms microbial community structure analysis with PCR-DGGE

Figure 6 showed the DGGE profiles after denaturing gradient gel electrophoresis for 16 kinds of DNA from the epiphytic microbial community in biofilms. It could find that each sample of epiphytic biofilms on the surface of different matrix was isolated with various electrophoresis strips after denaturing gradient gel electrophoresis analysis, DGGE bands of different biofilm samples revealed significant difference. The DGGE bands from the aquatic plant surface during the traditionally activated sludge process and the $\mathrm{A}^{2} / \mathrm{O}$ process were seven, and the DGGE bands from the gravel surface in natural reservoir water 


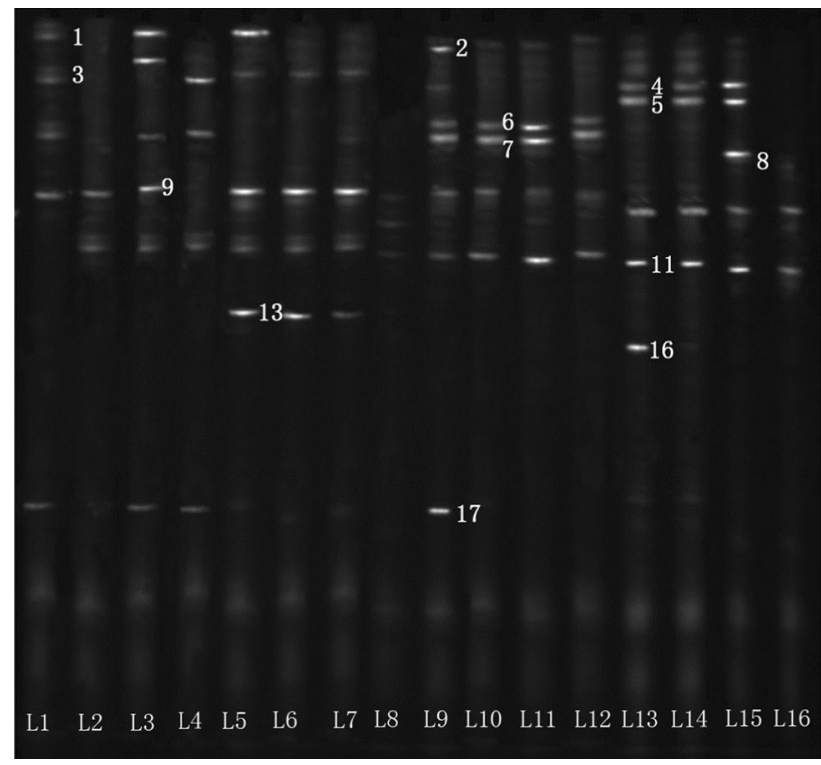

Fig. 6 DGGE band pattern of 16S rDNA PCR from 16 biofilms. L1L16 stand for SMLP, SMLS, SLLP, SLLS, RJLP, RJLS, RJRP, RJRS, RGLP, RGLS, RGRP, RGRS, RQLP, RQLS, RQRP, RQRS, respectively

from Yongdinghe Mencheng Lake were two. Figure 7 showed the phylogenetic tree of the dominant bacteria in different biofilm samples.

Moreover, as shown in Figs. 6 and 7, the number of microbial species in the biofilm of aquatic plants was more than that on the pebble surface. All biofilm samples had four kinds of strains such as Pseudomonas sp. CP1b, uncultured Acinetobacter sp. clone 3P-3-2-D21, Acinetobacter sp. 7-15 and Comamonas sp. 01xTSA12A_H10. Although different biofilm samples contained similar bands somewhat, the specificity of advantage bands existed. The dominant bacteria of the biofilm in reclaimed water during the combinatorial process of coagulation and sand filtration were Acinetobacter sp. 7-15 and uncultured Cyanobacterium; the dominant bacteria in water body biofilm during the traditionally activated sludge process were Pseudomonas sp. CP1b, Pseudomonas fluorescens strain CLW17, Chryseobacterium taichungense strain YNB68 and Comamonas sp. 01xTSA12A_H10. The dominant bacteria in the biofilm from water body during the UF membrane filtration plus anaerobic-anoxic-oxic process were uncultured $\mathrm{Aci}$ netobacter sp. clone SL35B-4, uncultured Acinetobacter sp. clone 402, uncultured Acinetobacter sp. clone SS38B062, uncultured Acinetobacter sp. clone JI71E112, and Comamonas sp. 01xTSA12A_H10. The dominant bacteria in the biofilms on the surface of different water bodies were also different. The dominant bacteria were uncultured Acinetobacter sp. clone 3P-3-2-D21, Acinetobacter sp. 2C56 and uncultured Firmicutes bacterium clone KWK6F.85. All of the above dominant bacteria are aerobic bacteria (Vestal and White 1989), which suggested a quite consistent result between PCR-DGGE and PLFA. Meanwhile, the complexity of microbial community was much lower in the reclaimed water biofilm than in the sewage biofilm. Nitrification and degradation of organic materials were very important in the process of biological sewage treatments, which could result in the competition of dominant bacteria, ammonia-oxidized bacteria and nitrite-oxidized bacteria as well as the spatial distribution associated with short-range nitrification and denitrification, or simultaneous nitrification and denitrification processes (Fdz-Polanco et al. 1996). This is mainly due to that the content of organics in sewage is higher and the organic compositions in sewage is more complex, which can provide sufficient nutrients to different microorganisms (Gan and Bai 2010). Therefore, there are much slower competition and much simpler spatial distribution between microorganisms in the reclaimed water biofilm than in the sewage biofilm. As a result, the types and content of microorganisms in the sewage biofilm are significantly more than those in the recycled water. Moreover, the longer history of natural water can result in a higher microbial evolution degree of water biofilm, thus leading to the production of protozoa in biofilms. On the other hand, there were no protozoa detected in the reclaimed water.

\section{Biofilms organic components}

The content of the extracellular proteins and extracellular polysaccharides in the attached biofilms from the surface of 16 kinds of matrix were shown in Fig. 8. First, the total content of EPS in the biofilms attached on the surface of gravels was $20.78-410.02 \mu \mathrm{g} / \mathrm{mL}$, and that on aquatic plants was $77.63-500.44 \mu \mathrm{g} / \mathrm{mL}$. So the former was less than the latter by $18.1-78.4 \%$. This may be due to that the portion surface of aquatic plants in water received more light that provided more energy for microbial photosynthesis and growth (Liang et al. 2013). Another possible reason should be that most of the particles in aquatic plants surface biofilm skeleton were large particles (Liang et al. 2013). So, the biofilm skeleton had a large number of pore channels that was beneficial to the transmission and absorption of nutrients and pollutants, which as a result accelerated the microbial decomposition of pollutants. In contrast, the microorganisms on gravel surfaces received less energy, and the dense pore structures were unfavorable to their growth and adsorption of pollutants. Therefore, the biofilms attached on aquatic plants had more EPS. Secondly, the total content of EPS of biofilms in reclaimed water treated by combinatorial process of coagulation and sand filtration was $121.89-339.13 \mu \mathrm{g} / \mathrm{mL}$, and that by UF membrane filtration plus anaerobic-anoxic-oxic process was $84.02-500.44 \mu \mathrm{g} / \mathrm{mL}$, and that by activated sludge 
Fig. 7 Phylogenetic tree of predominant bacteria from 16 biofilms

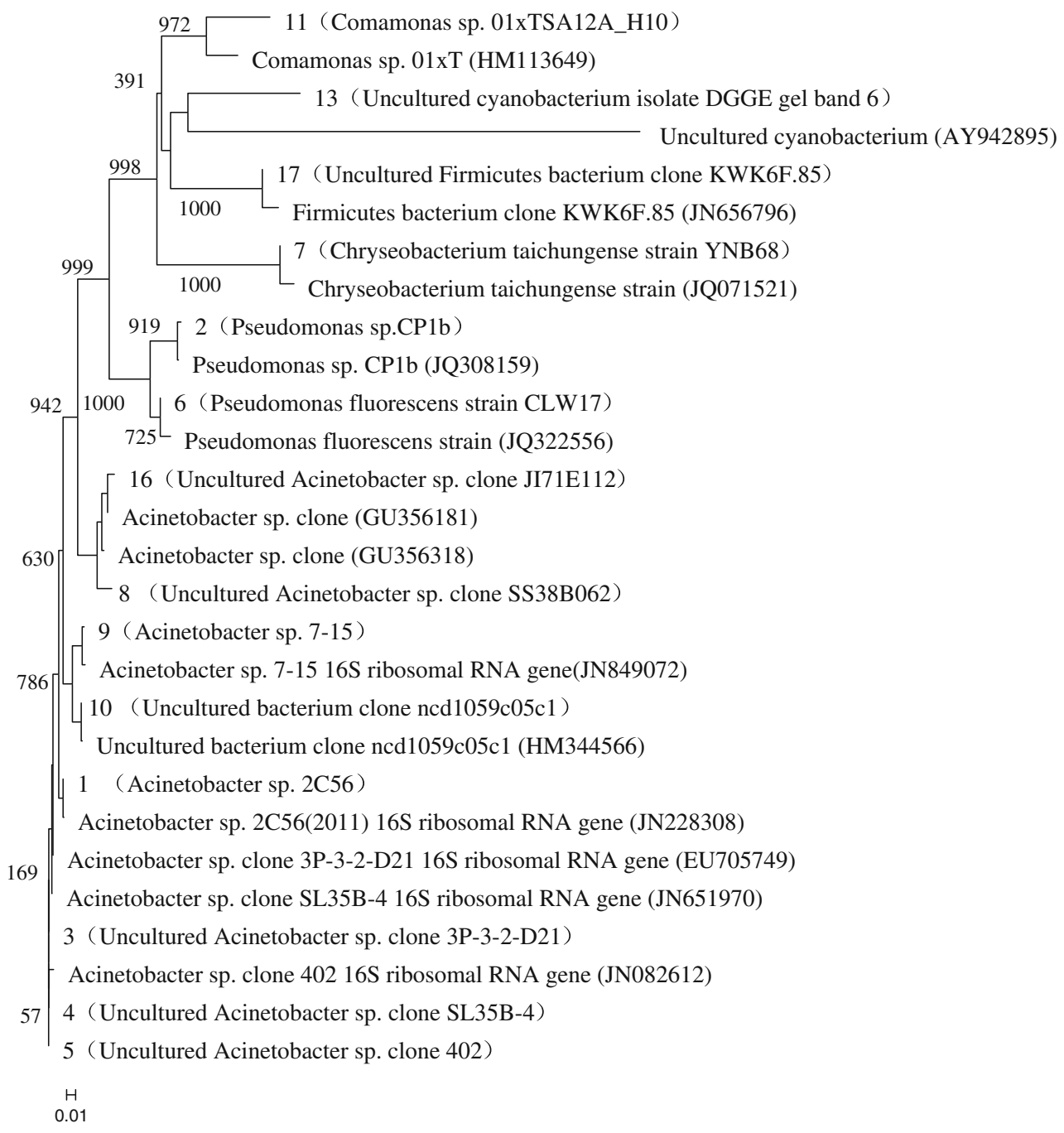

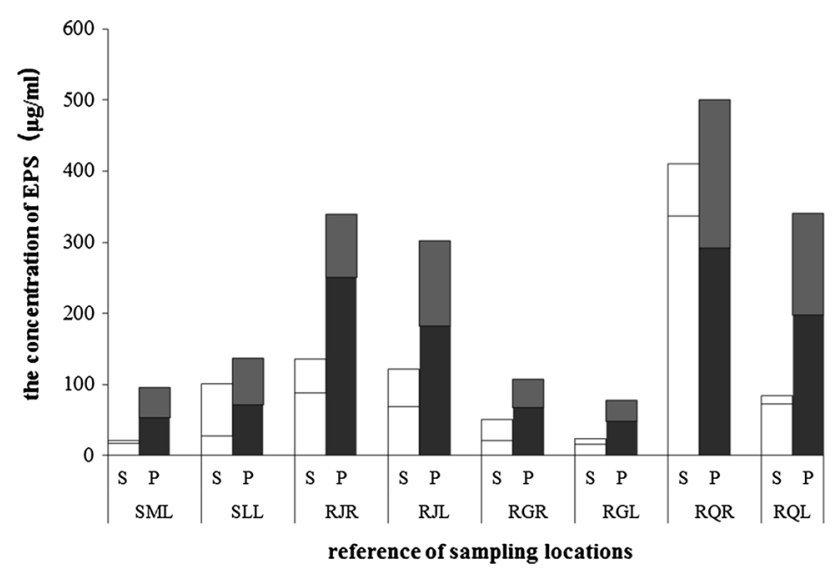

Fig. 8 Histogram of EPS's concentration in the attached biofilms from different water. The upper part of the bar is extracellular proteins' concentration, the lower part of the bar is extracellular polysaccharides process was $23.20-107.52 \mu \mathrm{g} / \mathrm{mL}$. The total content of EPS of biofilms in nature water was $20.78-137.24 \mu \mathrm{g} / \mathrm{mL}$. Meanwhile, on the surface of gravels, the total content of EPS in the biofilms was $111.2 \%$ higher during the combinatorial process of coagulation and sand filtration, and $303.9 \%$ higher during the UF membrane filtration plus anaerobic-anoxic-oxic process when compared with that in natural water; similarly, the total content of extracellular proteins was $32.8 \%$ higher in the combinatorial process of coagulation and sand filtration and $11.3 \%$ higher in the UF membrane filtration plus anaerobic-anoxic-oxic process when compared with that in natural water; the total content of extracellular polysaccharides was $243.4 \%$ higher in the combinatorial process of coagulation and sand filtration and $798.6 \%$ higher in the UF membrane filtration plus anaerobic-anoxic-oxic process when compared with that in natural reservoir water. In addition, on the surface of 
aquatic plants, the total content of EPS in the attached biofilm was $174.2 \%$ higher during the combinatorial process of coagulation and sand filtration and $260.0 \%$ higher during the UF membrane filtration plus anaerobic-anoxicoxic process when compared with that in natural water; the total content of extracellular proteins was $90.2 \%$ higher during the combinatorial process of coagulation and sand filtration and $222.6 \%$ higher during the UF membrane filtration plus anaerobic-anoxic-oxic process when compared with that in natural water; the total content of extracellular polysaccharides was $247.5 \%$ higher in the combinatorial process of coagulation and sand filtration and $292.5 \%$ higher in the UF membrane filtration plus anaerobic-anoxic-oxic process when compared with that in natural water. However, in the reclaimed water during the activated sludge process, the total content of EPS in the biofilms was lower than that in natural reservoir water. Generally, the contents of extracellular proteins, extracellular polysaccharides and EPS on the gravel surface revealed the reduction by $51.4,18.8$ and $39.3 \%$, respectively. Moreover, on the surface of aquatic plants, the contents of extracellular proteins, extracellular polysaccharides and EPS exhibited the reduction by 36.7, 6.8 and $20.7 \%$, respectively. This was mainly due to the reclaimed water treated with different processes. The combinatorial process of coagulation and sand filtration can improve the clearance rates of BOD and COD only up to $60 \%$ and UF membrane filtration plus anaerobic-anoxic-oxic process can result in a removal rate of more than $80 \%$ for BOD, the clearance rate of BOD of the activated sludge process was 90-95 \% (Gan and Bai 2010). There are still much more nutrients and pollutants in the first two kinds of reclaimed water than the latter. So, two kinds of reclaimed water can provide enough nutrients for microorganisms that can secrete EPS. Thus, the total content of EPS of biofilms in reclaimed water treated by combinatorial process of coagulation and sand filtration and UF membrane filtration plus anaerobic-anoxic-oxic process both were higher than that of biofilms in reclaimed water treated by activated sludge process.

Besides, the content of 14:0 was decreased with the increase of total content of EPS in the river water biofilms and the aquatic plant surface biofilm. The content of 18:0 was increased with the increase in the content of extra-

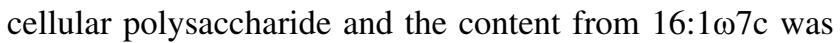
increased with the increase in the content of extracellular proteins in the lake water biofilm. However, whether other water bodies have similar change trend remain unknown. By comparing matrix surface characteristics of biofilms from different water bodies, the characteristics of the biofilm from the water subjected to the traditionally activated sludge treatment process have an obvious difference when compared with other two processes.

\section{Conclusion}

Biofilm was a typical porous matrix that absorbed a lot of particles such as inorganic particles, microbes (rod-shaped bacteria, spherical bacteria, filamentous bacteria and ring bacteria) and algae. The pores between these particles were filled with a lot of sticky materials such as EPS. The amount of algae in biofilm grown in lakes was larger than that in rivers. The visible microorganism in the biofilm attached on the surface of aquatic plants had 2-5 types, while 1-2 types were on the surface of gravels.

The proportion of calcite and quartz was approximately $50 \%$ in the biofilm. The biofilm attached on aquatic plants in the reclaimed water and reservoir water had more calcite, which accounts for 31.30 and $43.21 \%$; while the biofilm on gravels had more quartz, which accounts for 23.85 and $35.54 \%$. The biofilms attached on the gravels had less EPS than those on aquatic plants, and so as extracellular polysaccharide and extracellular albumen.

The PLFA results have demonstrated that the biofilm microorganisms in the water were mostly bacteria; PLFA species in the biofilm were generally in the range of 2-7; PLFA in biofilm attached on aquatic plant was 4-7 types; and PLFA on gravel surface samples had 2-6 types. Dominant bacteria in the reclaimed water bodies were Acinetobacter, Cyanobacteria aeruginosa, Pseudomonas fluorescens, Chryseobacterium and Comamonas, while the dominant bacteria in natural water body were Acinetobacter and Firmicutes.

In conclusion, many advanced equipment and technology, such as ESEM, X-ray diffractometer, PLFA biomarkers and PCR-DGGE can make a fine test on the features of attached biofilms. Totally, the work has studied the morphology, structure and component characteristics of attached biofilms on the aquatic plant surface. Meanwhile, the gravel surface in eight kinds of water has also made meaningful research results. However, the work was only limited to the situ sampling to study the biofilm attached on the surface of water matrix, not the whole situation of the rivers and lakes ecosystem, which may be influenced by the background. Moreover, there is lack of the research methods for the treatments of reclaimed water. Whether the water is in a normal or excellent situation only can be judged by the attached biofilm. Therefore, it is necessary for us to make deeper research on the unique rivers and lakes.

\section{References}

Liang MC et al (2013) Structural and fractal characteristics of biofilm attached on the surfaces of aquatic plants and gravels in the rivers and lakes reusing reclaimed wastewater. Environ Earth Sci. 70(5):2319-2333 
Baty AM (1996) Adhesion of biofilms to insert surfaces: a molecular level approach directed at the marine environment. Biofouling 10(1-3):111-121

Costerton JW, Stewat PS, Greenberg EP (1999) Bacterial biofilms: a common cause of persistent infections. Science 284:1318

Dong D, Yang F, Li Y, Hua X, Lü X, Zhang J (2005) Adsorption of $\mathrm{Pb}, \mathrm{Cd}$ to $\mathrm{Fe}, \mathrm{Mn}$ oxides in natural freshwater surface coatings developed in different seasons. J Environ Sci 17(1):30-36

Dong DM et al (2006) Comparison of components and distribution of heavy metals in sediments, suspended particulate matter and surface coatings in natural waters. Chin J Geochem 25(1):200201

Fdz-Polanco F, Villaverde S, Garcia PA (1996) Nitrite accumulation in submerged biofilters-combined effects. Water Sci Technol 34 (3-4):371-378

Felsenstein J (1985) Confidence limits on phylogenies: an approach using the bootstrap. Evolution 39:783-791

Frølund B et al (1996) Extraction of extracellular polymers from activated sludge using a cation exchange resin. Water Res 30 (8): 1749-1758

Gan YP, Bai Y (2010) The advanced treatment and recycling technologies in sewage treatment plant. China Architecture \& Building Press 7(1):198-314

Hong L, Herbert HP (2002) Extraction of extracurricular polymeric substances (EPS) of Sludges. J Biotechnol 95(3):249-256

$\mathrm{Hu} \mathrm{X}$ et al. (2005) Chemical components and heavy metals in sludge from wastewater treatment plant. J Agro Environ Sci 24(2):387391

Huang JP, Wu LY (2008) Standard implementation guide for urban sewage recycling. Standards Press of China, Beijing

Juanico M, Friedler E (1999) Wastewater reuse for river recover in Serni and Israel. Water Sci Technol 40:43-50

Kumar S, Tamura K, Nei M (2004) MEGA3: integrated software for molecular evolutionary genetics analysis and sequence alignment. Brief Bioinf 5:150-163

Li JY, Zuo H, Luan ZK, Zhu BX et al (2002) Effects of substrate conditions on compositions of extracellular polymeric substances in biofilms. Environ Chem 21(6):546-551

Lowry OH, Rosebrough NJ, Farr AL (1951) Protein measurement with the Folin phenol reagent. J Biol Chem 193(1):265-275
Nocker A et al (2007) Response of estuarine biofilm microbial community development to changes in dissolved oxygen and nutrient concentrations. Microb Ecol 54(3):532-542

Pennanen $\mathrm{T}$ et al (1999) Structure of the microbial communities in coniferous forest soils in relation to site fertility and stand development stage. Microb Ecol 2:168-179

Percival SL (1998) Biofilm development on stainless steel. Water Res 32(1):243-253

Picioreanu C, Loodrecht MCM, Heijinen JJ (2001) Two-dimensional model of biofilm detachment caused by internal stress from liquid flow. Biotechnol Bioeng 72:205-218

Qin SY (2008) Study on morphology and biodiversity of biofilm of river oder. $\mathrm{PhD}$ thesis, Harbin Institute of Technology

Qiu LP, Ma J (2005) Characters of biofilm and its microorganism population in biological aerobic filter. China Environ Sci 25 (2):214-217

Reichert P, Wanner O (1997) Movement of solids in biofilms: significance of liquid phase transport. Water Sci Technol 36 (1):321-328

Sandhu A, Halverson LJ, Beattie GA (2007) Bacterial degradation of airborne phenol in the phyllosphere. Environ Microbiol 9:383-392

Sergi S, Helena G, Anna R (2002) The effect biological factors on the efficiency of river biofilms in improving water quality. Hydrobiologia 469:149-156

Vestal JR, White DC (1989) Lipidalysis in microbial ecology: quantitative approaches to the study of microbial communities. Bioscience 39:535-541

Wang WJ et al (2002) Element contents of biofilm and suspended particulate in natural aquatic ecosystem. Chin J Appl Ecol 13 (8): 1001

Wei F (2002) Water and exhausted water monitoring analysis method. China Environmental Science Press, Beijing. ISBN 7-80163400-4

Xing FD, Ren NQ, Gong ML (2005) Application of PCR-DGGE to resolve microbial diversity in bio-hydrogen producing reactor. Environ Sci 26(02):172-176

Yu YX, Wu GQ, Meng XT (1990) Environmental engineering microbiology manual. Chinese Environmental Science Press, Beijing 